\title{
AN INSTITUTIONAL APPROACH TO THE ANALYSIS OF KLEPTOCRATIC ECONOMY IN THE CONTEXT OF EUROPEANIZATION
}

\author{
Robert Pustoviit ${ }^{1}$, Oleg Kuklin ${ }^{2}$, Mykhailo Kryvoruchko ${ }^{3}$
}

\begin{abstract}
Relevance. Kleptocratic economy, as an institutional system, is oriented towards a key function that involves gaining wealth by the ruling elite through the introduction of non-market transaction costs for companies and households, which is based on administrative, bureaucratic, and political violence. For this purpose, the kleptocratic states create such systems of state institutional management that give the authorities the possibility of rent-oriented behaviour, which impedes the functioning of the real sector of the economy and encourages the shadow one. Under such circumstances, transaction costs are redirected to administrative intervention into the market mechanism, rather than aimed at increasing its efficiency; property rights are not clearly specified; the level of uncertainty about rules and norms of economic behaviour increases, and the motivational system of business activity is distorted. As a result, on the one hand, inefficient allocation of resources and slow economic growth (decline) are observed, and on the other hand, there is the redistribution of income in favour of the ruling elite and its excessive enrichment, that is detrimental to the welfare of the majority of the population. The aim of the article is to analyse the political-economic formation of a kleptocratic basis, which in the future transforms the state and its economy into kleptocratic formations; defining ways of counteraction and institutional capacity for transformations in the direction of Ukraine's aspirations for European integration. Methodological basis. The methodological basis of the research is the work of domestic and foreign scientists in the field of institutionalism and kleptocratic economy. The models of the development of a kleptocratic state and the influence of kleptocratic factors on the socio-economic processes in the country have been studied with the application of the method of analysis, systematization, and generalization. Results. It is determined that in order to liquidate the grounds of kleptocratic economy, it is of primary necessity to eliminate institutional obstacles that interfere with the unification of the legal and shadow sectors of the economy and ensure their institutional formalization. This requires the introduction of effective ways of restraining the ruling elite in order to restrict corruption abuses of the government and its close reigning coalition with special privileges and bureaucracies and form an institutional structure, in which firms and households have clearly defined property rights and also have the possibility to protect contractual rights provided by formal institutes. Particular attention should be paid to the ways of civil society's monitoring the state information policy and methods of adopting laws, which is, the institutional foundation that guarantees the openness of information as to the actions of government institutions. According to the results of the study, definite measures are proposed, the implementation of which will ensure the opportunities for Europeanization, particularly in Ukraine. The emphasis is placed on the fact that the important factors of counteracting the kleptocratic economy are the wage reform and the "transparent" selection of employees in the public administration sector on the basis of their professional qualities only.
\end{abstract}

Key words: kleptocratic economy, corruption, institutional environment, formal and informal institutions, European integration process.

JEL Classification: B52, D73, F20

\footnotetext{
Corresponding author:

${ }^{1}$ Cherkasy State Business-College, Ukraine.

E-mail: rfpustovit@gmail.com

ORCID: https://orcid.org/0000-0003-0188-2677

${ }^{2}$ Cherkasy State Business-College, Ukraine.

E-mail: kuklin_oleg@ukr.net

ORCID: https://orcid.org/0000-0001-6904-3496

${ }^{3}$ Cherkasy State Business-College, Ukraine.

E-mail: m.y.kryvoruchko@gmail.com

ORCID: https://orcid.org/0000-0001-6150-864X
} 


\section{Introduction}

The kleptocratic economy as an institutional system is oriented to the key function, which is associated with the gaining of wealth by the ruling elite through the introduction of non-market transaction costs for firms and households, which is based on administrative, bureaucratic, and political violence. For this purpose, kleptocratic states create such systems of state institutional governance, which give those who are in power the possibility of rent-oriented behaviour, which impede the functioning of the real sector of the economy and encourage the shadow one. Under such circumstances, transaction costs are redirected to administrative intervention into the market mechanism, rather than to increase of its efficiency; property rights are not clearly specified, the level of uncertainty about rules and norms of economic behaviour increases, and the motivational system of business activity is distorted. As a result, on the one hand, inefficient allocation of resources and slow economic growth (decline) are observed, and on the other hand, the redistribution of income in favour of the ruling elite and its excessive enrichment, detrimental to the welfare of the majority of the population. It should be emphasized that the obstacles of the kleptocratic character, first of all, corruption and the oligarchic nature of the economy, cannot be eliminated in the short term and are the key barriers for Europeanization of postSoviet countries, including Ukraine's accession to the EU and its accelerated economic growth.

Actually, the issue of kleptocratic factors and their negative impact on economic development is being widely researched by Ukrainian scholars and foreign scientists. For example, in the works of V. Predborsjkyj and $\mathrm{M}$. Fomina, the critical influence of corruption on the state's economy, in particular, the domestic one, and the danger of shadowing of its socio-economic processes are analysed (Predborsjkyj, 2005; Fomina, Prykhodjko, Kapturenko, 2012); O. Dlughopoljsjkyj investigated the minimization of the negative influence of corruption on the Ukrainian economy (Dlughopoljsjkyj, 2012). Regarding foreign publications, in the context of the proposed article, particular attention should be paid to the works that focus on kleptocratic aspects, namely, scientific publications: D. Acemoglu (Acemoglu, Robincon, Verdier, 2004), S. Rouz-Ekerman (Rouz (Edmund, 2004), J. Campos (Campos and Pradhan, 2007), J. Labsdorff (Lambsdorff, 2007), B. Bloom (Vloom, 2014). With regard to perspectives and challenges to European integration processes in Ukraine, L. Danilenko, V. Polishchuk (Danylenko and Polishhuk, 2013), I. Rafaljsjkyj (see Rafaljsjkyj, 2011), O. Yunin (Yunin, 2018) actively work in this field of science.

\section{Research objectives and methodology}

Regardless of the volume of research work done towards analysing kleptocracy, there is a need for systematizing and institutional specification of the kleptocratic economy. Of particular importance in the context of this problem is the possibility of employing the institutional approach that allows investigation of the kleptocratic factor, which acquires an exceptional negative significance for the Europeanization processes, both within and outside the EU. Particular attention should be paid to the analysis of the correlation between kleptocracy and economic development in Ukrainian in the light of European integration.

Therefore, the aim of the article is to analyse the political and economic formation of the kleptocratic basis, which further turns the state and its economy into the kleptocratic one, to define methods of counterwork and institutional capacity to make transformations in the direction of Ukraine's aspirations for European integration.

In order to attain the abovementioned aim, the following research objectives should be reached within the scope of this study:

1. To define kleptocracy as a phenomenon.

2. To provide an overview of the anti-corruption area in the European Union with regard to differences between older Member States and the new ones with the post-socialist past.

3. To analyse kleptocracy in Ukraine in the light of European integration.

4. To apply an institutional approach to the analysis of kleptocratic economy in a broad sense.

5. To develop a theoretical concept of a path of fighting against kleptocracy in the context of Europeanization based on an institutional approach.

The methodological basis of the research is the work of domestic and foreign scientists in the field of institutionalism and kleptocratic economy. The models of the development of a kleptocratic state and the influence of kleptocratic factors on the socio-economic processes in the country have been studied with the application of the method of analysis, systematization, and generalization.

\section{Defining kleptocracy}

According to experts' viewpoint, the main obstacles to Ukraine'saccession totheEuropean Unionare corruption and slow reforms, as evidenced by a sociological survey conducted by the Democratic Initiatives Foundation named after Iljko Kucheriv (Interfaks Ukraine, 2015). In its turn, corruption is defined as a destructive, in relation to the formal institutes and actual generally accepted moral rules in the country, a system of socio-economic relations, characterized by the use of official authority powers to obtain material and (or) intangible benefits (Geveling, 2001). There are different kinds, types, and forms of corruption. Its economic component is the most dangerous for the sustainable development of the country. It is defined as unlawful use by government 
officials of their authority to specify property rights for their personal mercenary purposes. For example, a bribe for granting permission for business or for expediting the passage of customs procedures can be qualified as the appropriation of assets officially owned by the state. Obviously, bureaucratic services provided by government officials should be carried out not for self-enrichment of an official, but for giving economic entities the opportunity to implement economic activity as efficiently as possible. However, licenses, permits, quotas - all that necessitates compliance with formally written laws and regulations and outlines private economic activity - can be used by government officials at their own discretion to receive bribes.

The final configuration of corruption is the "seizure of the state" (Nisnevich, 2012), in which state power is privatized by ruling political-economic groups, powercoercive authorities and administrative resources are directed to the seizure of natural resources and land, the main flows of financial resources, state and private property, and estates of the most profitable economic assets (both in the public and private sectors), as well as the most influential means of disseminating information. In the "seized" state, which is defined as a state with kleptocratic economy, political and economic corruption turns to be systematic and becomes the basis for the functioning of the state, superseding competition, and contributing to the formation of monopolies subordinated to the ruling group in the political, economic, informational, and other spheres of activity of society and state.

\section{An overview of the anti-corruption area in the European Union}

Kleptocracy issues are directly related to corruption. The EU as a strategic partner of Ukraine attracts much attention in the light of high standards in socio-economic development, governance, and rule of law. At the same time, the issue of corruption within EU member states cannot be omitted within the framework of this study.

The report prepared by The Greens/European Free Alliance Group in European Parliament (The Greens/ EFA) in 2018 provides data on losses of European and national GDP from corruption. The report authors have estimated the total loss of GDP from corruption at the level of 904 billion euro annually that includes indirect effects of corruption such as losses in tax revenue and decreased foreign investment. The Greens/EFA report authors conclude that such amount of funds could be used to solve some global problems, e.g. ending world hunger, eliminating malaria, providing universal safe water and sanitation, etc. (The Greens/EFA, 2018).

Official Report on Anti-Corruption Policy prepared by the European Commission in 2014 was based on Eurobarometer surveys. The report data allows one making a conclusion on the high level of significance of the issues related to the perception of corruption among EU citizens. For instance, three-quarters of respondents think that corruption is widespread in their countries (especially in Greece, Italy, Lithuania, Spain, and the Czech Republic); a quarter of Europeans consider their daily lives are directly affected by corruption (especially in Spain, Greece, Cyprus, Romania, Croatia). The report data shows a similar picture of corruption in a business environment. That is to say, around 50\% of European companies consider corruption to be a serious problem, especially in construction and telecom/IT sectors. The countries, in which the businesses suffer from corruption the most, are the Czech Republic, Portugal, Greece, and Slovakia (European Commission, 2014).

Therefore, corruption causes serious losses for socio-economic development in the European Union. Regardless of the initial intention of the European Commission to publish the EU Anti-Corruption Report every two years after 2014, the EU Anti-Corruption Report was not published in 2016 (see Nielsen 2017). In addition, the European Commission has limited public access to the content of the 2016 EU Anti-Corruption Report (Darbishire, 2017).

Carl Dolan, Director of Transparency International EU, delivered a comprehensive summary on the progress of EU Anti-Corruption policy, implemented by the European Commission. Mr. Dolan in his speech in the European Parliament's workshop "How to better combat fraud? Follow up of the Commission's anti-corruption experience sharing programme" has concluded on the absence of significant progress in anticorruption policy (Dolan, 2018).

Therefore, there should be formulated a conclusion on stating the fact that corruption is a serious issue and challenge within EU countries. Regardless of a significant volume of analytical work done towards researching corruption, the EU governing bodies have not reached feasible progress in anti-corruption policy, as well as abolished public access to data on this policy after the publication of the first and the only EU AntiCorruption Report in 2014.

The study on corruption in the selected EU countries, conducted by the European Parliament Research Service in 2017, allows comparing anti-corruption policy progress in the EU members both who had and did not have a socialism experience in their history (EPRS, 2017). Particularly, the research focused on Finland, the United Kingdom, France, Germany, Italy, Croatia, Romania, and Bulgaria.

The three post-socialist countries - Bulgaria, Croatia, and Romania - have made a harmonization of their national legislative framework in the area of anticorruption policy according to respective European legislation. During the process of these countries' accession to the EU, their anti-corruption legislative frameworks were recognized as adequate. However, compared to Finland, Germany, UK, France, and Italy, 
these post-socialist countries are at the bottom in the anti-corruption rating list across the EU. An interesting conclusion that could be drawn from the considered study on corruption is related to the irrelevance of a functioning/non-functioning of a specialized anticorruption authority to the level of corruption (Finland and Germany do not have one, while other considered countries do). Another important conclusion from the considered study is that Croatia, Bulgaria, and Romania are highly centralized countries comparing to highly or relatively decentralized Finland, Germany, France, Italy, and the UK. Therefore, a high level of centralization could be noted as one of the factors sustaining a favourable ground for corruption in the EU countries that have a socialist past.

\section{Kleptocracy in Ukraine in the light of European integration}

For Ukraine as a whole, corruption factors are characterized as system-forming, which make it possible to characterize the Ukrainian economy as kleptocratic one (Acemoglu, Robincon, Verdier, 2004), when the institutional basis of kleptocratic economy is the corrupt foundation of the power structure and, identical to it, socio-political elite whose members dangerously violate public formal institutions, use their powers to quickly enrich and strengthen key positions in society. The terms "kleptocracy" and "elite" correlate to some extent, and it is due to the fact that the community of high-ranking corrupt officials acquires some of the features of the latter, although in reality it functions as a "kleptocratic quasi-elite" (Geveling, 2001).

It is the kleptocratic system that directly affects the level of economic development of Ukraine, which is extremely low (Table 1).

Table 1

Main macroeconomic indicators of Ukraine in 2017 (KNOEMA, World Data Atlas)

\begin{tabular}{|c|l|c|}
\hline 1. & GDP, bln USD & 109,32 \\
\hline 2. & GDP on PPP, bln USD & 368,78 \\
\hline 3. & GDP per capita, USD & 2583 \\
\hline 4. & GDP on PPP per capita, USD & 8713 \\
\hline 5. & Consumer Price Index, \% & 14,4 \\
\hline 6. & Unemployment rate, $\%$ & 9,4 \\
\hline 7. & Current account balance, bln USD & -4 \\
\hline 8. & Total state debt, \% & 75,6 \\
\hline
\end{tabular}

According to the data of Table 1, in 2017, Ukraine's GDP per capita amounted to 8713 USD (taking into account purchasing power parity - PPP), that is almost 4 times less than the average European index. At the same time, according to the current EU rules, if GDP per capita of a member-state is below $90 \%$ of the average European level and GDP of some regions does not reach $75 \%$ of this level, then the country as a whole and (or) separate regions have the right for subsidies that are intended to pull up their revenues to the average European index. The amount of subsidies should be significant: not less than the size of all grants received by all countries of Central and Eastern Europe after their accession to the EU.

Consequently, the current state of Ukraine's economy is such that the country, if adopted in the EU, would be an unacceptably heavy financial burden on the overall budget of the association. This conclusion is in line with public opinion in the countries of Western Europe, the main donors of the EU budget (Bazhan, 2015).

Let's add that in 2014, a significant deterioration of the economic situation was caused by military operations in the east of Ukraine, which caused a chain reaction of imbalance in macroeconomic indicators. Among the main factors that determine the economic trends in 2015 were: low external and domestic demand due to the deceleration of economic growth; reduction of the purchasing power of the population due to a decrease of real incomes; outflow of investments. The lack of appropriate measures aimed at stabilizing the situation has led to an intensification of the economic downturn. Although according to analysts' assessment, since 2017, the Ukrainian economy has continued recovering from a slight positive growth in 2016, which led to an increase in the gross domestic product by about $1.5 \%$ (Yunin, 2018). At the same time, the crisis has shown the danger of focusing on the export-raw material model of development and the use of benefits associated with the relatively low labour cost. Overcoming of crisis and transition to sustainable economic growth depend on the effectiveness of cooperation between the state and business, increasing the efficiency of use of innovations and attracting investments. At the same time, the key obstacle to all mentioned above are corruption and the lack of public confidence in state institutions, the judiciary, and the law enforcement system.

It should be noted that the barriers of an economic nature can be eliminated in the medium term as a result of the outstripping pace of economic growth in Ukraine. However, the latter is possible only with favourable changes in the institutional character, first of all, in the field of counteracting kleptocratic factors in the economy.

At the same time, attention should be drawn to the conclusions made by IMF experts, who in 2016 prepared a separate report on the correlation between the level of corruption and the state of the economy in the country. According to the Global Competitiveness Report, while in 2013-2014 business representatives named corruption the second biggest problem in Ukraine, in 2016-2017 this problem came in the first place, whereas political instability was the second stated position. By comparing data of Transparency International and World Economic Outlook, IMF experts came to the conclusion that there is a significant correlation 
Table 2

The ranking of Central and Eastern European countries by the Corruption Perceptions Index and GDP per capita in 2017 (KNOEMA World Data Atlas)

\begin{tabular}{|c|c|c|c|c|}
\hline Country & $\begin{array}{c}\text { Corruption Perceptions } \\
\text { Index }\end{array}$ & Place in the world ranking & $\begin{array}{l}\text { GDP per capita, at constant } \\
\text { prices in } 2010, \text { USD }\end{array}$ & Place in the world ranking \\
\hline Poland & 60 & 35 & 15761 & 48 \\
\hline Lithuania & 59 & 37 & 16793 & 44 \\
\hline Latvia & 58 & 39 & 15553 & 50 \\
\hline Czech Republic & 57 & 43 & 22779 & 39 \\
\hline Slovakia & 50 & 53 & 19897 & 42 \\
\hline Romania & 48 & 58 & 10932 & 62 \\
\hline Hungary & 45 & 65 & 15648 & 49 \\
\hline Belarus & 44 & 67 & 6376 & 89 \\
\hline Bulgaria & 43 & 71 & 8312 & 75 \\
\hline Ukraine & 30 & 133 & 2992 & 123 \\
\hline Russia & 29 & 134 & 11411 & 61 \\
\hline
\end{tabular}

between the level of corruption and the rate of economic growth (Table 2). According to the calculations of the fund, improvement of Ukraine's performance in the International rating of corruption risks even on one position will lead to an increase in income growth per capita by $1.35 \%$ and investments - by $4 \%$. Therefore, if the level of corruption in Ukraine remains unchanged, by 2040 , Ukrainian incomes will still be only about $30 \%$ of the EU average index (Zanuda, 2017).

We also emphasize that the Association Agreement between Ukraine and the European Union in section "Financial Cooperation" presupposes that the EU undertakes to provide assistance to Ukraine within the framework of the relevant financial instruments. At the same time, assistance will be provided in accordance with the principles of expedient financial management and implies the effective prevention of fraud, corruption, and other abuses. To achieve this, Ukraine must implement the relevant provisions of the European Union legislation and reach a certain level of coherence of the Ukrainian legislation with the legal norms of the European Union.

The convergence of Ukrainian legislation with the modern European legal system will ensure the development of political, entrepreneurial, social, cultural activity of Ukrainian citizens, economic development of the state within the framework of the EU and will promote the gradual growth of the welfare of citizens, bringing it to the level the EU member-states have developed (Rafaljsjkyj, 2011).

\section{An institutional approach to the analysis of the kleptocratic economy}

It must be recognized that corruption is widespread in the world. In some countries in Africa and South America, such as Nigeria or Colombia, as well as in the countries of the former Soviet Union, incomes from corruption are likely to account for a significant proportion of the gross national product. From time to time, corruption cases also become public in developed countries; in particular, the most widespread are unlawful government spending on military orders or the use of private funds for an election campaign. However, economic studies of corruption are rather local. Generally, they focus on the institutional model of the "principal - agent" that analyses the relationship between the higher levels of government officials (principals) and the agent - an official who receives corrupt benefits from individuals who are interested in certain government preferences.

Under the conditions stated above, the concepts of the institutional economy can be used to study the institutions that are able to counteract the genesis of the kleptocratic economy. At the same time, the formal and informal institutions deserving priority are those whose research allows us to understand the institutional motives that create conditions for the undemocratic power of the kleptocratic quasi-elite and provide opportunities for eradicating corruption in the economy.

Unlike "insignificant" ("everyday") forms of corruption, "large-scale corruption" as the basis of the kleptocratic economy is deeply rooted in government structures, leads to illegitimate appropriation of tremendous assets, undermines legitimacy, and preserves socio-economic backwardness (Vloom, 2014). Thus, "large-scale corruption" differs from the "household" one in terms of involvement of high-level officials in corruption structures on the grounds of abuse of state power and the appropriation of significant amounts of social wealth.

At the same time, it should be noted that according to the scientific approach of H.-J. Lauth (Lauth, 2000), formal and informal institutions do not antagonize but demonstrate a kind of coexistence, which leads to the situation when preserving the formal shell, the institutions that seem to guarantee democracy and supremacy of law, either collapse from inside, or even, turn into their opposites. It is the impact of such 
"subversive institutions" that causes negative effects, and the process of "informal institutionalization" should be considered as a systemic "distortion" of the institutional environment during institutional transformation and subsequent degradation.

Hence, the prospects for institutional analysis of the kleptocratic economy require intense attention to the fundamental aspects of the functioning of the so-called "subversive institutions" that affect the processes of informal state governing. Ideal models of both formal institutes (constitutions and laws) and informal ones (particularly, traditions), can be represented in the form of equilibrium, which is characterized as a selfsupporting system and conditioned by limiting effects. In the case of the predominance of "subversive" institutions, we observe partial equilibrium that can be broken without excessive efforts under the influence of exogenous factors. Therefore, with the predominance of "subversive institutions" in the kleptocratic economy, there is no chance for lengthening but, on the contrary, the reduction of the possible term of the elite's stay in power, which stimulates it to revitalize the rent-oriented behaviour, on the one hand, and deprives the incentives to change the existing situation, on the other hand (Gelman, 2010). These conditions require considering such partial equilibrium of "subversive institutions" as a precedent of an "institutional trap".

Therefore, in order to withstand the kleptocratic factors in the economy, it is necessary to create an institutional environment that will counteract the corrupt economic ordering, eliminate barriers that lawabiding business faces, provide legitimate guarantees to entrepreneurship, and give responsibility and initiative that has been monopolized by the state bureaucracy to private hands.

To do this, first of all, it is necessary to solve such institutional problems as eliminating obstacles that prevent the consolidation of the legal and shadow sectors of the economy and ensure their institutional formalization. This requires the introduction of effective ways of restraining the ruling elite in order to curb corruption abuses of the government and its close coalition with special privileges and bureaucracy, and to form an institutional structure, in which firms and households have clearly defined property rights, as well as have the possibility to protect contractual rights, provided by formal institutes.

In addition to the above considerations, there is a theory "divide and rule", which explains how the kleptocratic economic system can be relatively stable in the long-term equilibrium (Chen, 2010). Under such a system, only a very small number of economic individuals can benefit from discriminatory redistributive policies implemented by corrupt authorities, while the vast majority of households are victims of kleptocracy. Factors that can help limit the effectiveness of the "divide and rule" strategy, as well as destroy the kleptocracy itself, are as follows: increasing positive expectations of rising prosperity as a result of elimination of the kleptocratic regime can contribute to counteracting it on behalf of the part of civil society, which will force the kleptocratic power to resign. At the same time, the elimination of the kleptocratic regime will be more impressive if different groups of citizens are directly bound by a common goal and common interests. The confrontation between social groups creates prerequisites for subordinating even more economic and political resources to corruption.

At the same time, in order for groups of interests to have a significant impact on regulatory policy, they should: firstly, have a strong influence on election results; secondly, legislators should constantly feel the danger of losing support of interest groups that brought them to power; thirdly, the services of the "police patrol" and the "fire guard" (McCubbins and Schwartz, 1984) should be effective in controlling the legislators, so that the corruption policy they carry out does not deviate from the outlined oligarchic groups (Zaostrovtsev, 2009). In this sense, the methods of economic policy that strengthen the economic influence of already dominating groups or weaken the counteracting groups are likely to upset the existing balance of political forces and cause unintended destructive effects on the economy of the country. In addition, economic reforms that do not take into account the most important political and institutional sources of inefficiency, but only superficially affect its symptoms, can cause a "reverse" movement, as they violate the "political principle of incentive compatibility" and eventually ruin the existing political equilibrium of the kleptocratic system and actual corrupt coalitions.

The foregoing is explained by the existence of two types of public order inherent in economic development (North, Wallis, Weingast, 2011). The "open access" order is characterized by economic development, democracy, prosperous and dynamic civil society with numerous organizations and an extensive system of impersonal social relations, which include the rule of law and the secure protection of property rights. In turn, the public order of "restricted access", on the contrary, is characterized by slow economic growth, small number of public organizations, heterogeneity of social relations, built on the principle of personal privilege, restriction of competition, selective execution of laws, vulnerability of property rights and kleptocratic groups striving to create corruption rent. As a result, society is plunged into a noncompetitive economy, disorder and violence, while the illegal economy is gaining momentum. Kleptocratic authorities only sometimes think about the positive or negative consequences of their decisions for society as a whole. They focus mainly on personal covetous interests, encouraging those who get corrupt rents for them, redistributing resources in their favour with the help of "obedient" law enforcement and judicial systems. 


\section{Institutionalization as a path of fighting against kleptocracy in the context of Europeanization}

It should be noted that the West's interestin establishing democratic principles of governance in the post-socialist part of Europe and in opening up new markets for itself is the motivational basis that led the EU to the policy of Europeanization. But the realization of its own interests in the region does not necessarily have to lead to the full institutional integration of the countries of Central and Eastern Europe into the European Union and could well be limited to a close association within the framework of the European Economic Area formed for this purpose. At the same time, taking into consideration the abovementioned problems in Ukraine, the peculiarity of the "reinforcement strategy through remuneration", which was largely followed by the EU in the process of expansion to the East, is to avoid the risks of "moral responsibility" for partner's actions: the governments of the countries concerned cannot count on the EU's assistance only because they need it, not taking into account the requirements put forward by the EU. After all, the formula of the balance between national interests and motivation of the EU candidate country for integration is derived: the government adopts EU rules if the benefits from its rewards exceed the internal costs of accepting these rules (Rafaljsjkyj, 2011).

The dynamics of the institutionalization process should be understood without leaving out of sight counteraction to the kleptocratic factors in the economy when various socio-economic processes transform their interactions into an institutional system, whose elements become common practice, which has remained unchanged for several generations and been confirmed in the real behaviour of people.

Therefore, the role of institutionalization lies in the fact that it is a factor of reducing uncertainty and the basis for predicting the behaviour of economic entities. Creating institutions society establishes certain types of social interaction, changes them to permanent and mandatory ones. Further, on this basis, a system of sanctions is developed. Creation of a clear institutional and role structure of interests in accordance with the norms and rules, that is approved by the majority of participants in the socio-economic process, can be considered the final stage of institutionalization of interests (Loginova, 2008). This means that institutionalization causes the creation of a set of norms and rules that define the context of existence and interaction of entities and is accompanied by the creation of organizations and institutions that ensure the stability of the functioning of the institution, its management, and control of activities.

The process of institutionalization during the period of reforms in Georgia (Aliyev, 2014) can be cited as an example, when the government managed to achieve positive results in the elimination of the so-called "Georgian criminal world" and counteract the factors of the kleptocratic economy. In terms of institutional economics, the state assumed the functions of protection of property rights, which were characteristic for informal institutions - the proximate participants of the shadow economy. At the same time, opportunities for the potential of corruption were substantially limited, as the process of relations between the authorities and business became as deindividualized and automated as possible.

\section{Conclusions}

Thus, in order to eliminate the underlying cause of the kleptocratic economy, it is necessary first and foremost to eliminate institutional obstacles that interfere with the unification of the legal and shadow sectors of the economy and ensure their institutional formalization. This requires the introduction of effective ways of restraining the ruling elite in order to curb corruption abuses by the government and its close reigning coalition with special privileges and bureaucracies and form an institutional structure, in which companies and households have clearly defined property rights and also have the possibility to protect contractual rights, provided by formal institutes. Particular attention should also be paid to the ways of civil society's control over state information policy and the ways of laws adoption, that is, the institutional foundation that guarantees the openness of information about the actions of government institutions.

In turn, the Europeanization process presupposes making the necessary efforts to combat the kleptocratic economy; the struggle against certain individuals at power who are involved in corrupt acts; the provision of equality before the law, regardless of the position and property status, when the budget expenditures are carried out reasonably and in the interests of the society (EEAS, 2018), rather than separate kleptocratic clans.

The specification of the above conclusion is the implementation in the social and economic policy of measures that will provide opportunities for European integration processes in Ukraine, in particular:

- political parties are financed transparently and consistently follow their defined political strategy and election promises;

- Parliament and other elected bodies are formed under a transparent electoral system and reflect the interests of all people;

- state policy presupposes resignation of the officials responsible for the continuation of the kleptocratic policy of officials and imposing on them appropriate sanctions, including criminal ones;

- administrative services should be accessible and convenient for business and should not create corruption opportunities; 
- selection of civil servants should be competitive and transparent, based on their professionalism;

- ownership right is inviolable and guaranteed by effective protection mechanisms;

- corruption is not encouraged by imperfect legislation, and all known manifestations of it are punishable, regardless of the influence of a person who committed the crime;

- justice is fair and accessible; the rule of law is respected in the country.

Other important factors in counteracting the kleptocratic economy that restrain the European integration processes in Ukraine are the wage reform and the transparent selection of employees in the public administration sector on the basis of their professional qualities. At the same time, there should be introduced such a system of stimuli that personifies the effectiveness of employees in the field of remuneration and penalties, depending on their productivity. Synchronously, a key deterrent to the corruption intentions of civil servants is a reliable and unbiased system of continuous monitoring of their incomes and expenditures, which implies the inevitability of severe punishment for corruption.

Finalizing this study, one should say that the institutional approach allows developing a concept of institutionalization as a path of fighting against kleptocracy in the light of Europeanization. While European integration is a comprehensive process, the key issue is progress in anticorruption policy. Based on the experience of the former socialist republics, which joined the EU (Croatia, Bulgaria, and Romania), the state officials, civil society, and the general public should be aware of the correlation between a high level of centralization (inherited from the socialist past) and the level of corruption.

Further development of this research line could take a form of study (studies) on comparing the anticorruption policy progress between all EU member states with a socialist past, as well as between the EU members without such past. Understanding of common past and historical differences will enable to develop and formulate an institutional approach to the analysis of the kleptocratic economy and overcoming it.

\section{References:}

Acemoglu, D., Robinson, J., \& Verdier, T. (2004). Kleptocracy and Divide-and-Rule: A Model of Personal Rule. Journal of the European Economic Association, 2(2-3), 162-192.

Aliyev, H. (2014). The Effects of the Saakashvili Era Reforms on Informal Practices in the Republic of Georgia. Studies of Transition States and Societies, 6(1), 19-33.

Bazhan, A. I. (ed.) (2015). Evrointegratsiya Ukrainy: perspektivy, posledstviya i politika Rossii [European integration of Ukraine: perspectives, consequences and Russia's policy]. Moskva: In-t Evropy RAN. (in Russian)

Bloom, B. (2014). Criminalizing Kleptocracy? The ICC as Viable Tool in the Fight Against Grand Corruptions. American University International Law Review, 29(3), 628-656.

Campos, J., \& Pradhan, S. (2007). The Many Faces of Corruption. Washington: The International Bank of Reconstruction and Development, The World Bank.

Chen, X. (2010). Theory of Divide-and-Rule: Kleptocracy and Its Breakdown. University of Warwick Research Paper. Retrieved from: https://warwick.ac.uk/fac/soc/economics/intranet/manage/calendar/chen_jmp.pdf (accessed 30 October 2018).

Danylenko, L. I., \& Polishhuk, I. V. (2013). Perspektyvy ta vyklyky jevrointeghracijnykh procesiv dlja Ukrajiny [Perspectives and challenges of European integration processes for Ukraine]. Kyiv: NADU. (in Ukrainian)

Darbishire, H. (2017). EU Anti-Corruption Report. Retrieved from: https://www.asktheeu.org/en/request/ eu_anti_corruption_report (accessed 20 February 2019).

Dlughopoljsjkyj, O. V. (2012). Suchasni poghljady na korupciju ta minimizaciju jiji neghatyvnogho vplyvu na ekonomiku Ukrajiny [Modern views on corruption and minimization of its impact on Ukrainian economy]. Ekonomika Ukrajiny, 9, 13-24. (in Ukrainian)

Dolan, C. (2018). EU Anti-Corruption: Less is Less. Transparency International EU. Published on June 21, 2018. Retrieved from: https://transparency.eu/less-anticorruption (accessed 25 February 2019).

European Commission (2014). EU Anti-Corruption Report.

European External Action Service (2018). Assotsiatsiya ES - Ukraina: chto eto dast vam [The EU-Ukraine Association: how you benefit from it]. Retrieved from: http://www.eeas.europa.eu/archives/delegations/ukraine/ documents/virtual_library/association_115x170_ru.pdf (accessed 25 October 2018). (in Russian)

European Parliamentary Research Service (2017). Corruption in the European Union: Prevalence of Corruption, and AntiCorruption Efforts in Selected EU Member States. September 2017. Retrieved from: https://publications.europa.eu/en/ publication-detail/-/publication/ccb3441e-d580-11e7-a5b9-01aa75ed71a1/language-en (accessed 22 February 2019). Fomina, M. V., Prykhodjko, V. V., \& Kapturenko, M. Gh. (2012). Korupcija i tinjova ekonomika: politekonomichnyj aspekt [Corruption and shadow economy: political-economic aspect]. Donetsk: DonNUET. (in Ukrainian)

Gelman, V. (2010). «Podryvnye instituty» i neformalnoe upravlenie v sovremennoy Rossii [ Subversive institutions» and informal management in the modern Russia]. Politiya, 2, 6-24. (in Russian)

Geveling, L. (2001). Kleptokratiya. Sotsialno-politicheskoe izmerenie korruptsii v negativnoy ekonomike [Kleptocracy. Social-political dimension of corruption in a negative economy]. Moscow: Izd-vo «Gumanitariy» Akademii gumanitarnykh issledovaniy. (in Russian) 
Interfaks Ukraina (2015). Zarubezhnye eksperty schitayut osnovnymi prepyatstviyami na puti Ukrainy $k$ chlenstvu $v$ ES korruptsiyu i medlennye reformy - opros [Foreign experts considers corruption and slow reforms to be the main obstacles for Ukraine on its way to the EU membership - jury of opinion]. Retrieved from: https://interfax.com.ua/ news/political/292307.html (accessed 25 October 2018). (in Russian)

KNOEMA. World Data Atlas: Ukraine. Retrieved from: https://knoema.com/atlas/Ukraine?origin=knoema. ru\&_ga=2.140136565.717356440.1540653995-1601292816.1540653995 (accessed 27 October 2018).

Lambsdorff, J. G. (2007). The Institutional Economics of Corruption and Reform: Theory, Evidence and Policy. Cambridge: Cambridge University Press.

Lauth, H.-J. (2000). Informal Institutions and Democracy. Democratization, 7(4), 21-50.

Loginova, L. (2008). Mekhanizm institutsionalizatsii interesov [Mechanisms of the interests institutionalization]. Filosofiya i obshchestvo, 4, 146-157. (in Russian)

McCubbins, M., \& Schwartz, Th. (1984). Congressional Oversight Overlooked: Police Patrols versus Fire Alarms. American Journal of Political Science, 28, 165-179.

Nielsen, N. (2017). EU Commission Drops Anti-Corruption Report. EU Observer. Published on February 02, 2017. Retrieved from: https://euobserver.com/institutional/136775 (accessed 05 February 2019).

Nisnevich, Yu. (2012). Mnogolikaya korruptsiya i ee izmereniya v issledovaniyakh mezhdunarodnykh organizatsiy i mezhdunarodnykh otnosheniy [Many-sided corruption and its dimensions in the studies conducted by international organizations and international relations]. Mirovaya ekonomika, 3, 83-90. (in Russian)

North, D., Wallis, D., \& Weingast, B. (2011). Nasilie i sotsialnye poryadki. Kontseptualnye ramki dlya interpretatsii pismennoy istorii chelovechestva [Forcing and social order. Conceptual framework for interpretation of a scriptory history of humanity]. Moskva: Izdatelstvo Instituta Gaydara. (in Russian)

Rafaljsjkyj, I. (2011). Polityka jevrointeghraciji ta jiji rolj v procesi nacionaljnogho samovyznachennja [European integration policy and its role in the process of national self-identification]. Visnyk NTUU «KPI», 4(12), 67-72. (in Ukrainian)

Rouz-Ekerman, S. (2004). Korupcija ta urjaduvannja. Prychyny, naslidky ta zminy [Corruption and governance. Roots, causes, and changes]. Kyiv: «K.I.S.».

Predborsjkyj, V. A. (2005). Detinizacija ekonomiky v konteksti transformacijnykh procesiv. Pytannja teoriji ta metodologhiji [Unshadowing of economy in the context of transformational processes]. Kyiv: Kondor. (in Ukrainian) The Greens / European Free Alliance (2019). The Cost of Corruption Across the EU. Published on December 7 , 2018. Retrieved from: https://www.greens-efa.eu/files/doc/docs/e46449daadbfebc325a0b408bbf5ab1d.pdf (accessed 15 February 2019)

Yunin, O. Sevruk, V., \& Pavlenko, S. (2018). Priorities of Economic Development of Ukraine in the Context of European Integration. Baltic Journal of Economic Studies, 4(3), 358-365. doi: 10.30525/2256-0742/2018-4-3-358-365

Zanuda, A. (2017). MVF podschital poteri ekonomiki Ukrainy [IMF estimated losses of Ukraine's economy]. Retrieved from: https://www.bbc.com/ukrainian/features-russian-39512756 (accessed 30 October 2018). (in Russian)

Zaostrovtsev, A. (2009). Teorii grupp interesov [The groups of interests theories]. Finansy $i$ biznes, 1, 6-24. (in Russian) 